\title{
Security Measures. A Comparative Analyze between Albanian and Italian Legislation
}

\author{
Nikolin Hasani \\ Faculty of Human Sciences, Department of Law, University “Ismail Qemali” Vlorë, \\ Vlorë, Albania \\ nikolin.hasani@univlora.edu.al
}

\begin{abstract}
Personal freedom of the person consists in the freedom of the latter from any coercion that prohibits or restricts it in motion or action. As part of positive freedoms, which are realized and stand next to negative freedoms, the personal freedoms are considered as freedom in the state.
\end{abstract}

The purpose of this paper is to bring a complete picture of the evolution of security measures according to the Albanian legislation through a comparative analysis with the Italian Criminal Procedure Codes.

Keywords: security measure, legislation, comparative analyze.

\section{INTRODUCTION}

Albanian Code of Criminal Procedure was approved in 1995 and entered into force the same year, this code should be considered as a contemporary variant and as its model the legislator has chosen the Italian Code of Criminal Procedure, however this code is studied carefully and It is faced with the situation, traditions and the concrete conditions of our country. Since the Albanian Criminal Procedure Code is created on the basis of the Italian Criminal Procedure Code, the changes will be few, because the similarities dominate.

Italian Criminal Procedure Code was adopted in 1988 and entered into force in 1989. This code is divided into 11 books, where security measures are included in the fourth book, which is divided into two titles, where in first are included personal security measures, while in the second the property security measures. This code ironically is called as "code of professors" almost impossible to implement in practice, however, this code has managed to withstand frequent changes of its.

\section{A Short Historical OVERView OF Security Measures of 1979-S in Albania}

Criminal Procedure Code of People Socialist Republic of Albania approved with Law No. 6609 date 25 December 1979, enter into force on 01 April 1980. This code remained in force till 01 August 1995, when with Law No.7905 date 21 March 1995, is approved the new Code of Criminal Procedure. Code of year 1980 by Law No.7086 date 08 May 1990 became the amendment related with the allowance of defense with lawyer, by Law No.7536 date 17 December 1991 were repealed the provisions that polities the penal process. With law no. 7574, dated 24 June 1992, "On the organization of justice and some changes in the codes of criminal and civil procedures ", changed the judicial system and was created the Court of Cassation and the Court of Appeal. These changes came as a result of change of political system in Albania.

Criminal Procedure Code of People Socialist Republic of Albania as well as the other acts or laws in force, during the communist period, was completely politicized and doctrinated by socialist spirit that prevailed in the country. In this code are reflected and sanctioned the revolutionary principles of the leadership and politics of party, war of classes and implementation of mass line. This code announced the dependence of courts from politics, took off to prosecutor the functions of penal persecution, denied a defense by lawyer, reconfirmed the right of investigator to take security and controls measures, not recognizing to the court the right of control and approval of most important procedural actions for the preliminary investigation stage. In this code were denied all the democratic principles and standards of penal proceeding and were accepted opposite rules with them. The main purpose that legislator followed through security measures was the defense of socialist justice, setting it at a 


\section{Nikolin Hasani}

superior and untouchable plan, this always in the spirit of a life and a society completely collective in which dominated volunteerism. In the first plan the ratio between authors suspected for criminal offense and the state. Is left entirely in second plan the ratio between suspected author for committing the criminal offense and the victim, the ratio between the suspected author and self-criminal offense committed by him. The security measures according this code, have to especially with the limitation of freedom of person that as the rule is taken as defendant for committing of criminal offense, while the other procedural coercive measures implemented to find, collect, fix the material evidences, to guarantee the order in court hearing, to guarantee the presentation of the defendant and the other persons at the investigator or court, to prevent the continuation of criminal activity. Some of these measures (detention, forced bringing, removal of persons from the courtroom), in difference from the security measures can be implemented against to the persons who were not taken before as defendant. Security measures take a very important place in the system of procedural coercive measures. In article 47 of the Criminal Procedure Code of 1980 is said that: "To ensure the right and fast development of investigation , of the trial, the court, the single judge and the investigator have the right to take security measures against a person who is taken as a defendant". The Criminal Procedure Code of 1980 doesn't recognize and does not provide the institute of duration of security measures, doing so these measures have an undefined duration, leaving the defendant available to the investigation, for all the time that it considers necessary. This code provides two very important institute, the removal and change of security measures. In Article 51 is provides that the security measure can be remove only when this is determined by court or investigators. In the moment of change of security measures by the investigator, always needed the approval of prosecutor, however from what it results from content of article 6, this approval has to do only with procedural side of investigation action and has not to do with the approval by prosecutor of fact if we are in conditions to change or not the security measure.

As a conclusion, it must be said that the Code of Criminal Procedure of Popular Socialist Republic of Albania is a code where the fundamental human rights and the rights that belong to the prosecution are completely vulnerable, leading in this way the violation of these rights, sanctioning also the absolute rights of investigation and court, by placing them in a superior position.

\section{Comparative Analyze between the Albanian Criminal Procedure Code and THE ITALIAN CODE REGARDING TO SECURITY MEASURES}

\subsection{The Types of Security Measures}

Albanian Criminal Procedure Code in its Article 227 which is the article that begins the title of security measures, makes the traditional separation of personal security measures concretely into coercive and prohibitive measures. Such a disposition lacking in the Italian code of criminal procedure, where the e first disposition of the book of security measures begins with the general disposition, in which is sanctioned that freedom of the individual may be restricted only under the dispositions of this code and only through security measures. Such a provision in the Albanian code we can find only in Article 5 point 1. As in the Albanian code of criminal procedure and in Italian code translation of criminal procedure, in personal security measures are included coercive and prohibitive measures. But the Italian code of criminal procedure in Chapter VII, in the context of the personal security measure includes security measures, which are temporary and are precursors to personal security measures. Such provisions is not found in the Albanian code of criminal procedure.

\subsection{The Conditions for Security Measures}

In Article 273 of the Italian code of criminal procedure, are provided the general conditions for security measures, these conditions are: the existence of serious indications of guilt (gravi indizi di colpevolezza); the existence of a criminal offense; non- implementation of security measures when there are causes of impunity or cessation of the criminal offense. These conditions are found in the Albanian code of criminal procedure to, but with the difference that the Italian code requires the existence of "gravi indizi di colpevolezza", that is nothing else but the reference to the elements necessary of evidence and sufficient for affirmation of criminal offense. In Albanian code this element is translated into the existence of reasonable suspect based on evidences. Specific criteria for taking security measures are the same in both codes, but with a difference where in the Italian code in the case of leaving or risk of leaving of the defendant is provided that the criminal, offense for which the defendant is suspected to provide imprisonment punishment for not less than two years at the 
maximum. This provision is not found in the Albanian code and that only in the case of detention of suspects for committing the offense is required such a thing. In the letter c of article 274 of the Italian criminal procedure code, where is provided the possibility that the person may commit another more severe criminal offense, is ranked one of the few criminal offenses that a person can commit, again such a provision is absent our code. Both codes are led at the time of arrest in prison, by the principle of proportionality and appropriateness, as well as the exemption under which the security measure cannot be applied to a pregnant woman or lactating women, to a person over seventy years, to a seriously ill person. What is noted in Italian code of criminal procedure, is that in disposition of Article 275 are not included drug addicts and alcoholics, and in paragraph 3 of its are provided several criminal offenses for which should take offense, we don't find this in our procedure code. For determination of offenses, it applies the same reasoning as above, who have only determinant and orientation role, but never exhaustive. Point 3 of Article 230 of the Albanian code of criminal procedure does not find reflection in the Italian procedure code, this provision is necessary to not leave place for abuse. In connection with the provisions of the minor, different from Albanian code which dedicates only a few paragraphs to the implementation of a security measure to the minor, in the Italian code we find some articles for the implementation of this measure to minors, based on the principle "to protect the youth", providing the institutions necessary for this purpose. In Articles 16, $17,18,19,20$, of Italian code is provided the conditions and criteria to be taken into account in determining security measure against a minor or in the implementation of arrest in flagrante or detention, conditions and criteria which must considered together with the conditions and criteria provided in Articles 274, 275, 276 of the Italian code of procedure. In Article 231 of the Albanian code of criminal procedure, as well as article 276 of the Italian criminal procedure code, provides the right of the court to replace or join the security measure to another in case of breach by the defendant of the duties and conditions derived from the criminal offense. Article 277 of the Italian criminal procedure code, explicitly sanctions the fact that during the implementation of security measures should be kept in mind by the Court the fundamental rights and freedoms of the person against whom is taken this measure, such disposition we do not find in Albanian code of procedure because the legislator is sufficed by definition of Article 1 of the Code which expressly states: " Criminal procedural legislation has a duty to provide a right, equal and legally regular procedure, to protect personal freedoms and the rights and lawful interests of citizens, to contribute for strengthening of law order and the implementation of the Constitution and the laws of the state ". Article 278 of the Italian Code, provides the completion of the implementation of security measures, again such s disposition is missing in our code, because such a provision is included indirectly in the dispositions of Articles of title of security measures. In Article 279 of the Italian Code of Criminal Procedure, is provided that who is the judge, who will determine the security measure, revoke or replace it during the proceedings in court or during the preliminary investigations. This provisions has no place in the Albanian code of criminal procedure, since in Articles 13, 14, 74, 75, 76, 278, 327 etc, is determined who will be the court that will have jurisdiction and such a prevision under article 279 of the Albanian code of criminal procedure, I appreciate that it is redundant.

\subsection{The Content of Security Measures}

In Albanian code of criminal procedure are provided seven security measures, while according to the dispositions of Italian code of criminal procedure, the security measures are six, where the property guarantee according this code is not security measure. Since the similarities between two codes are numerous, regarding to the content of security measures, we stop only on analysis of differences.

In case of prohibition of leaving the country, the only difference is in the fact that according to point 2 of article 281 of Italian code of criminal procedure, the judge in the moment when disposes by decision for assignment of security measure, expect the measure requested by prosecutor can set the implementation of prohibition of leaving the country, I appreciate that such a provision will not do anything else but will deteriorates the defendant, for more that the coercive nature of security measures does not allow leaving the country. At prohibition and the obligation to stay in a certain place, the only difference consists at point 4 of article 283 of Italian code of criminal procedure, which attaches great importance to the defendant's personal interests. The security measure of house arrest brings a substantial difference between the two codes and that relates to the fact that, according to the Italian code of criminal procedure, the defendant against whom it is applied the house arrest is on the same conditions as the defendant against whom it is applied arrest in prison, while according to 


\section{Nikolin Hasani}

Albanian criminal code, the defendant against whom is applied the security measure of house arrest is on the same conditions as the defendant against whom is implemented the arrest in prison only in terms of the length of detention. Such thing is reflected in the practice of the respective courts, the Italian jurisprudence allows the replacement of arrest in prison with house arrest or vice versa.

The content of the disposition of arrest in prison by the Albanian code of criminal procedure is curtailed because is limited only with sanction of the fact that with the decision of imposition of security measure of arrest in prison, the court orders the judicial police to catch the defendant and send it to the institution of detention, and the same rules are valid in the case of the security measure set as a result of the request for extradition, in this case the Albanian code of criminal procedure, suffice with the provision of dispositions of Articles 493 and 494, which talk about coercive measures and their temporary implementation in the case of the extradition request. At the person who take advantage by non-implementation of their arrest in prison are people with HIV or severe immune disease, if we were in front of such a situation, will be face with a legal vacuum of Albanian code of criminal procedure. Italian Criminal Procedure Code, except two prohibitive measures provided by our code, provides to the prohibition of the exercise of parental rights. The essential difference that exists between the two codes related to the amount of punishment provided for the criminal offense for which the defendant is suspected, where according to the Albanian code of criminal procedure, the measure of imprisonment should be higher in maximum than a year, while Italian code provides that the measure of imprisonment should be more than three years, and in this code is specified that those actions should affect the public administration, in the case of suspension of the exercise of a duty or public service, and in the case of the prohibition of exercising of certain professional or commercial activities the criminal offenses should be committed against to a public activity, the public economy, industry and service.

\subsection{The Formality of Security Measures}

The formality of security measures finds the same reflection in both codes, but even in these dispositions there are differences. In the case of determining of the security measure the difference is that in the Italian code is not provided the fact that the judge cannot assign a security measure more severe than that requested by the prosecutor, and it is explicitly stated that the judge can dispose with decision to implementation of a measure easier than that required by the prosecutor, only in the case when the prosecutor in his request did not ask the implementation of a specific measure. In connection with a decision for determining of a security measure, the difference is only in the naming of the person to whom is taken this measure, which according to our code, is said for the defendant and for the person against whom is taken this measure, while the Italian code, in all its dispositions says about the defendant.

\subsection{The Duration of Security Measures}

At the time of the interrogation the difference is in the term within which this procedural action should be done, where according to the Albanian code, the deadline is three days, while for the Italian code the deadline is five days, and for the house arrest the term is fifteen days. The duration of security measures for both codes is different during the trial at first instance and on appeal trial, where for the Albanian code in trial at first instance are these terms: for the respective crimes, 2 months, 9 months, 12 months; for the Italian code 6 months, 12 months, 18 months. For the trial in appeal the Albanian code provides these terms: 2 months, 6 months, 9 months; for the Italian code 9 months, 12 months, 18 months. The overall duration according to the Criminal procedure Code is 10 months, 2 years, 3 years; while for the Italian code is 2 years, 4 years, 6 years. In the institute of extension of detention is different only the fact that in Albanian code the duration of detention cannot stop $2 / 3$ of measure of punishment, while Italian code requests not to be past $1 / 2$ of maximum of punishment. For the duration of prohibitive measure must be said that for Albanian code, is 3 months while for Italian code is 2 months. In the case of dispositions for the defendant's release from prison, the Italian code, has set a deadline of 20 days within which the judge must act, while our code has not limited in time the judge. Arrest in flagrante or detention of suspect differs in the two codes only in terms of the country in which the legislator has chosen to impose, where according to the Albanian code is part of the title of security measures, while according the Italian code, is part of the title of preliminary investigations, since these procedural actions are related to the activity of the judicial police. 


\section{Conclusion}

Regarding to the differences that resulted from the comparative analysis between the two legislations we give the following recommendations:

Deferring to the classification of security measures, I evaluate that the most appropriate provision is that of the Italian code of criminal procedure, because such as a provision is in function of the fundamental rights and freedoms of defendants.

Referring to the provision of the possibility that a person may commit another heavier criminal offense, provision which absent in the Albanian code, I appreciate that such a provision is not necessary to be sanctioned, as when is provided the possibility that the person to commit an criminal offense more serious or another of the same type, means that in this whole is included a large number of criminal offenses and that their provision according to the Italian procedure code has no more than a determining and orientation role , but never exhaustive.

D Referring to the principle of proportionality, suitability and exclusion, I appreciate that the exclusion of drug addicts and alcoholics constitute negative discrimination to positive discrimination that provides Article 275 of the Italian code, and as such, the inclusion of this category by article 230 of the Albanian code, constitutes a nondiscriminatory positive element.

$>$ Referring to the implementation of coercive measures, the Italian code determinates that they can be implemented only when the person is suspected of committing a criminal offense for which the measure of imprisonment is not lower in maximum than three years, in the Albanian code we do not find such a provision, and I think that such a provision would be necessary, to not leave place wrong practices applied by prosecuting authorities, which and for an criminal offense which provides imprisonment not less than two years in maximum requests and implement the security measure of arrest in prison.

Deferring to the long timeframe during which the judge should act in case of dispositions of the release of the defendant from prison, term, which for the Albanian code in difference from the Italian code is undefined, I appreciate that of a such term is in function of not extension of proceedings. The appeal in general is the same in both codes, but the way submitted by the Criminal Code, I think it is more appropriate, given that presents the most complete and detailed right of appeal.

$>$ Referring to the difference between the two codes regarding to the arrest in flagrancy or detention, I appreciate that the solution according to the Albanian code, related to the fact that arrest in flagrancy or detention are subjected to the conditions and criteria determinate for security measures, while the solution according to the Italian Code it seems that request to disconnect and separate the flagrancy arrest or detention of suspect from security measures, linking them more to the activity of the judicial police during the preliminary investigation.

In conclusion, I think that with all the advantages or disadvantages that can have each of these two codes will be considered as codes that have brought innovative and contemporary ideas, this brings the impossibility of determining of the best.

\section{REFERENCES}

[1] Anastasi, A. \& Omari, L. (2010), E drejta Kushtetuese, Ribotim. Tiranë 2010.

[2] Anastasi, A., \& Omari, L. (2010). E drejta kushtetuese, Ribotim. Tiranë 2010, fq. 139-140.

[3] Çela, K., Elezi, I. \& Gika. (1982). E Drejta Penale e Republikës Popullore Socialiste të Shqipërisë, Pjesa e Përgjithshme. Tiranë 1982.

[4] Conde, M. \& Aran, G. (2004), Derecho penal - Parte Generale. Valencia 2004.

[5] Conso, G. \& Grevi, V. (2003), Compendio di Procedura Penale. 2nd ed. fq. 373, Cedam 2003.

[6] Conso, G. \& Grevi, V. (2003), Compendio di Procedure penale, 2nd ed. Cedam, 2003.

[7] Conso, G. \& Grevi, V. (2003), Compendio di Procedure penale. 2nd ed. Cedam, 2003.

[8] Conso, G. \& Grevi, V. (2003). Compendio di Procedura Penale, 2nd ed. fq. 366, Cedam 2003.

[9] Elezi, I. \& Elezi, E. (2010). Historia e së drejtës penale. Erik, Tiranë 2010.

[10] Elezi, I. \& Hysi, V. (2006). Politika Penale. PEGI, Tiranë, 2006. 
[11] Elezi, I. (1982), E drejta penale e Republikë Popullore Socialiste të Shqipërisë. Universiteti i Tiranës, Tiranë, 1982.

[12] Elezi, I. (1997). Zhvillimi i legjislacionit penal shqiptar.

[13] Elezi, I. (2001). Komentar i shtesave dhe ndryshimeve në Kodin Penal. Albin, Tiranë 2001.

[14] Elezi, I. (2002). E drejta penale e Republikes se Shqiperise. Tirane, 2002.

[15] Elezi, I. (2004). Komentari i shtesave dhe ndryshimeve të reja në Kodin Penal 2003- 2004. Albin, Tiranë, 2004.

[16] Elezi, I. (2005). E drejta Penale Pjesa e Posaçme. Tiranë 2005.

[17] Elezi, I. (2007). E Drejta Penale, Pjesa Posaçme. Botime Erik, 2007

[18] Elezi, I. (2008). E drejta penale - Pjesa e përgjithshme. 2008.

[19] Gjoka, A. \& Shoshi, E. (1999). Komente mbi masat e sigurimit personal. Botime "Geer", Tiranë 1999.

[20] Kodi i Procedures Penale te Republikes se Shqiperise, Neni 173, paragrafi 1.

[21] Kodi i Procedures Penale te Republikes se Shqiperise, Neni 173, paragrafi 5.

[22] Kodi i Procedures Penale te Republikes se Shqiperise, Neni 178.

[23] Kodi i Procedures Penale te Republikes se Shqiperise, Neni 180.

[24] Kodi i Procedures Penale te Republikes se Shqiperise, Neni 181.

[25] Kodi i Procedures Penale te Republikes se Shqiperise, Neni 182.

[26] Kodi i Procedures Penale te Republikes se Shqiperise, Neni 227.

[27] Konventa për mbrojtjen e të Drejtave të Njeriut dhe Lirive Themelore, Romë

[28] Kodi i Procedures Penale te Republikes se Shqiperise, Neni 227.

[29] Kodi i Procedures Penale te Republikes se Shqiperise, Neni 173.

[30] Kodi i Procedures Penale te Republikes se Shqiperise, Neni 173, paragrafi 5.

[31] Konventa për mbrojtjen e të Drejtave të Njeriut dhe Lirive Themelore, Romë, 4.XI.1950

[32] Kodi i Procedures Penale te Republikes se Shqiperise, Neni 234.

\section{AUTHOR'S BIOGRAPHY}

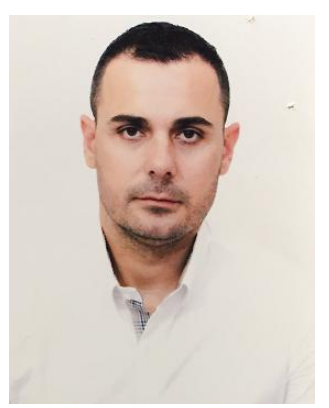

Ph.DNikolinHasani, Professor at Law Department, Faculty of Human Sciences, University "Ismail Qemali" Albania. Doctoral studies at Faculty of Law, University of Tirana, Albania. 